\title{
Level of Practice of Safety Precautions against COVID 19 among Pregnant Women Attending Antenatal clinics in Central Hospital Benin, Benin City in Nigeria
}

\author{
${ }^{*}$ OMOZUWA, ES; ${ }^{2}$ UWAIBI, NE; ${ }^{3}$ ERHABOR, JO \\ ${ }^{*}$ Department of Obstetrics and Gynaecology, Edo University Iyamho, Edo state, Nigeria \\ ${ }^{2}$ Department of Community Health, Edo University Iyamho, Edo state, Nigeria \\ ${ }^{3}$ Department of Obstetrics and Gynaecology, Stella Obasanjo Hospital, Country home motel road, Sapele road Benin City, Edo State, \\ Nigeria \\ *Corresponding Author Email: sunnyeghe@yahoo.com
}

\begin{abstract}
Coronavirus disease 2019 (COVID-19) has assumed a global health concern since the first case was recorded in Wuhan community China in December 2019. The objective of this paper is to report the level of practice of safety precautions against COVID 19 among pregnant women attending Antenatal Clinics in Central Hospital Benin, Benin City in Nigeria. A self- administered questionnaire on the level of practice of safety precautions against covid 19 infection was administered to a total of 420 pregnant women attending antenatal clinics in central Hospital Benin City for Data collection. The results showed that two hundred and four (48.6\%) of the respondents reported that they have recently avoided crowded places. Three hundred and seventy two $(88.6 \%)$ reported recently wearing mask whenever they left home. Three hundred and twenty four $(77.1 \%)$ of the respondents had good practice of safety precautions against COVID19. The study showed a good practice of safety precautions against COVID19 and this was influenced by the women's level of education, occupation and knowledge of COVID-19. However, there is still the need to improve the knowledge of the women attending antenatal clinic regarding COVID-19 through health education seminars. Also up scaling the practice of safety precautions could be done through such health education seminars.
\end{abstract}

\section{DOI: https://dx.doi.org/10.4314/jasem.v24i11.12}

Copyright: Copyright (C) 2020 Omozuwa et al. This is an open access article distributed under the Creative Commons Attribution License (CCL), which permits unrestricted use, distribution, and reproduction in any medium, provided the original work is properly cited.

Dates: Received: 20 September 2020; Revised: 29 October 2020; Accepted: 10 November 2020

Keywords: Pregnant women, Practice, Safety precaution, covid-19

Coronavirus disease 2019 (COVID-19) has assumed a global health concern since the first case was recorded in Wuhan community China in December 2019 (WHO, 2020). The virus is a single stranded RNA belonging to the Coronaviridae family with several genotypes and has a diameter of $65-125 \mathrm{~nm}$. The novel virus is a member of the beta group of coronaviruses and was named the 2019 novel coronavirus (2019nCov). Thereafter, the International Committee on Taxonomy of Viruses (ICTV) named the virus SARSCoV-2 on February 11, 2020 and the disease as COVID-19 (Shereen et al, 2020; ICTV, 2020). The World Health Organization (WHO) declared the novel coronavirus (COVID-19) outbreak a global pandemic on March 11, 2020 (Lai et al, 2020) and since then COVID-19 has spread very quickly across the 6 continents of the World including Nigeria. Globally COVID-19 has led to 3.68 million cases with over 258 thousand deaths while in Nigeria 2,950 confirmed cases with 98 deaths (Lai et al, 2020; WHO, 2020). COVID-19 is an infectious viral disease which affects mainly the respiratory system (WHO, 2020). The disease is transmitted through direct contact with respiratory droplets of an infected person (generated through coughing and sneezing). Individuals can also contact it through touching of infected surfaces such as eyes, nose and mouth ( $\mathrm{Li}$ et al, 2020). While contact with contaminated objects and surfaces have also been identified as a major route of transmission Lu et al (2020). Droplets typically cannot transverse more than six feet (almost two meters) (Makoni, 2020), SARS$\mathrm{CoV}-2$ remains intact and contagious in droplets and can be suspended in the air for up to three hours Additionally, contaminated droplets can settle on objects such as plastic, stainless steel, copper, and cardboard (Makoni, 2020); Mullard, 2020). A person can become infected if they touch the surface contaminated with SARS-CoV-2 objects and then make contact with mucous membranes such as the eyes, nose, or mouth (Makoni, 2020). This is why health authorities advised frequent hand-washing with soap and water (Makoni, 2020). The symptoms of COVID-19 include fever, dry coughing, and fatigue that may lead to serious complications, such as difficulty in breathing, chest pain, difficulty in talking, and immobility Beigel et al, (2020). Every aspect of Human life is affected by coronavirus disease (COVID-19) pandemic and a worldwide public health 
response has been engaged to address the impact (WHO, 2020). Currently, focus has been on the highrisk populations, including older people and people with serious underlying medical conditions, with little or no attention to other susceptible populations at risk such as the pregnant women (WHO, 2020; Zhong et al, 2020). Pregnant women are presently recognized as a population at increased potential risk (WHO, 2020). In pregnancy, women experience altered immunological and physiological response, with adverse complications that might make them more vulnerable to viral respiratory infections, such as influenza, severe acute respiratory syndrome (SARS) and Middle East respiratory syndrome (MERS). Beyond the virus-specific risks, illnesses with high grade fever in early trimesters of pregnancy are associated with specific birth defects, such as neural tube defects, miscarriages and fetal wastages (Kerr et al,2017; Lotfi et al, 2020) Quite a number of reports have been conflicting and inconclusive as to whether vertical transmission of SARS-CoV-2 can occur. Scanty data on the effect of COVID-19 and adverse pregnancy outcomes are available and studies already Published seem to be reassuring that pregnant women with COVID-19 might not be at increased risk for severe complications or adverse reproductive health outcomes (Dong et al, 2020). These studies have been limited to case series and case reports and lack sufficient numbers to merit infrequent risks attributable to COVID-19 infection in pregnancy (Lotfi et al, 2020; Haq et al, 2020).

Therefore the aim of this study is to determine the level of practice of the safety precautions for the preventions of COVID-19 among pregnant women attending ANC in central hospital Benin City in Nigeria.

\section{MATERIAL AND METHODS}

The study was carried out in Benin City which is the capital of Edo State. Central Hospital Benin is a secondary health facility owned and managed by the Edo State Government. This health facility was employed due to the fact that pregnant women obtained treatment from government-owned facilities. This study was done among pregnant women who gave their consent to participate and those on follow up visits

The sample size was determined using the Cochrane for single proportions

$$
\mathrm{n}=\mathrm{n}=\frac{\mathrm{Z}^{2} \mathrm{Pq}}{\mathrm{d}^{2}}
$$

Where: $\mathrm{P}=60.9 \%$, the proportion of knowledge of covid 19 among pregnant in a study carried in Abakalili, Nigeria, 2020.

Where $\mathrm{q}=1.0-\mathrm{P} ; \mathrm{d}=$ degree of precision at the $0.05 ; \mathrm{z}$ $=$ the standard normal deviate (1.96), which correspond to $95 \%$ confidence interval

Therefore

$$
\mathrm{n}=\frac{(1.96)^{2}(0.61)(0.39)}{0.05^{2}}=365.56
$$

Where $\mathrm{n}_{\mathrm{rr}}=$ non response rate $=10 \%=0.1$

Therefore,

$$
\mathrm{n}_{f}=\frac{365.56}{1.0-0.1}=406.1
$$

Study design: This study was a cross-sectional descriptive study.

Sampling technique: Systematic sampling technique was utilized for this study. The first study participant was selected using a simple random sampling technique by balloting.

Data collection: A self-administered questionnaire on awareness, knowledge, perception and practice of covid 19 infection was administered to the participant for data collection. The questionnaire was developed following review of literatures on the WHO recommendations on the measures to prevent humanto-human transmission of COVID-19 infection. The study questionnaire was divided into four areas: 1) socio-demographic characteristics (i.e., age, parity, marital status, area of residence, occupation, participant's level of education, and husband's level of education); 2)media exposure to access information about coronavirus infection pandemic; 3)knowledge about preventive measures against Coronavirus (COVID-19) infection (i.e., ever heard about coronavirus infection pandemic, multiple variables regarding symptoms, what to do when the participants suspect to have develop and made available under a CC-BY-NC-ND 4.0; 4) Practice of preventive measures against coronavirus infection. The variables used to assess the knowledge and practice of preventive measures of coronavirus infection were 1) Frequent hand washing with soap and water or rubbing alcohol-based sanitizers on the hand, 2) Maintaining at least 2-meter distance from others, 3) Avoiding touching eyes, nose and mouth with hands, 4) Covering mouth and nose when coughing or sneezing, 5) Wearing face mask in public, 6) Staying indoor. The questionnaire has 12-item scale (6-item for knowledge questions and 6-item for practice questions). The scoring system of women's knowledge and practice of 
preventive measures was either 2 (for correct answer) or 0 (for incorrect answer). The minimum score was 0 whereas the maximum score was 12 each for both knowledge and practice component of the questionnaire.

Scoring of Practice of safety precautions: Practice of safety precautions against COVID-19 was assessed using a Likert scale (Q27). A total of nine (9) subsets of question 27 were used to assess practice. The scale was scored accordingly: Never $=1$, Rarely $=2$, Sometimes $=3$, Most times $=4$ and Always $=5$. Minimum and maximum scores were calculated as 9 and 45 respectively and scores were converted to percentages and graded as follows, scores $29.9 \%$ and below were categorized as poor practice, scores $30.0 \%$ to $59.9 \%$ were categorized as fair practice and scores $60.0 \%$ and above were categorized as practice.

Data management: The data obtained was analyzed using SPSS version 20.0 statistical package. Mean and standard deviation (SD) were used to describe continuous variables and proportions for categorical data. chi-square $\left(\chi^{2}\right)$ was used for group comparisons to determine the significance of observed differences or association where applicable.

Ethical considerations: This was sought and obtained from the ethics and research committee of central hospital Benin City and permission to conduct the study was obtained from the head of department obstetrics and Gynecology and informed concert from participants

\section{RESULTS AND DISCUSSION.}

A total of 420 pregnant women participated in the study. One hundred and thirty four $(31.9 \%)$ of the respondents were aged $30-34$ years and $131(31.2 \%)$ were $25-29$ years (Table1). Three hundred and eighty eight $(92.4 \%)$ of the respondents were married while $26(6.2 \%)$ were single. Two hundred and twenty $(52.4 \%)$ of the respondents had secondary level of education and $165(39.5 \%)$ had tertiary education (Table1). Two hundred and eighteen $(51.9 \%)$ of the respondents had skill level II jobs and 79 (18.8\%) had skill level IV jobs (Table1). Two hundred and twenty nine $(54.5 \%)$ of the respondents were had parity of $2-$ 4 while $101(24.0 \%)$ had a parity of 1 (Table2). One hundred and sixty seven $(39.8 \%)$ were between $28-$ 32 weeks gestation and $84(20.0 \%)$ were $33-36$ weeks into their pregnancy while $81(19.3 \%)$ were term pregnancies $(37-40)$ (Table2). Two hundred and four $(48.6 \%)$ of the respondents reported that they have recently avoided crowded places. Three hundred and seventy two $(88.6 \%)$ reported recently wearing mask whenever they left home. Informing a health provider was the most popular precaution mentioned by the respondents if they were to have COVID19 symptoms as indicated by $339(80.7 \%)$ of the respondents. Three hundred and twenty five (77.4\%) stated the wearing a mask was the protocol to be followed if COVID19 symptoms were present while $312(74.3 \%)$ indicated that staying at home was their preferred protocol (Table3).

Table 1: Socio-demographic characteristics of the respondents $(\mathrm{N}$

\begin{tabular}{lll}
\multicolumn{2}{c}{$=420)$} & \\
\hline Variable & Frequency & Percent \\
\hline Age (years) & 5 & \\
$15-19$ & 59 & 1.2 \\
$20-24$ & 131 & 14.0 \\
$25-29$ & 134 & 31.2 \\
$30-34$ & 61 & 31.9 \\
$35-39$ & 30 & 14.5 \\
M40 & & 7.1 \\
Marital status & 26 & \\
Single & 388 & 6.2 \\
Married & 1 & 92.4 \\
Divorced & 3 & 0.2 \\
Separated & 2 & 0.7 \\
Cohabiting & & 0.5 \\
Level of education & 9 & \\
No formal education & 26 & 2.1 \\
Primary & 220 & 6.2 \\
Secondary & 165 & 52.4 \\
Tertiary & & 39.3 \\
Occupational class (ILO) & 36 & 8.6 \\
Unemployed & 67 & 16.0 \\
Skill level I & 218 & 51.9 \\
Skill level II & 20 & 18.8 \\
Skill level III & 79 & \\
Skill level IV & Mean age $=30.4 \pm 5.8 y e a r s ;$ \\
\hline
\end{tabular}

Table 2: Obstetric characteristics of the respondents $\mathrm{N}=420$

\begin{tabular}{lll}
\hline Variable & Frequency & Percent \\
\hline Parity & & \\
0 & 73 & 17.4 \\
1 & 101 & 24.0 \\
$2-4$ & 229 & 54.5 \\
$\geq 5$ & 17 & 4.0 \\
Estimated gestational age (weeks) \\
$\leq 12$ & 3 & 0.7 \\
$13-27$ & 82 & 19.5 \\
$28-32$ & 167 & 39.8 \\
$33-36$ & 84 & 20.0 \\
$37-40$ & 81 & 19.3 \\
$>40$ & 3 & 0.7 \\
\hline Mean parity $=1.9 \pm 1.4 ;$ Mean EGA & $=31.2 \pm 5.9$ weeks
\end{tabular}

One hundred and ninety $(45.2 \%)$ of the respondents reported washing hands with soap and water, 212 $(50.5 \%)$ of them most times rubbed their hands with alcohol based sanitizers and $287(68.3 \%)$ of the respondents sometimes maintained a social distance of 2 meters. Two hundred and thirty seven $(56.4 \%)$ of the respondents sometimes avoided touching hands, nose and mouth, $190(45.2 \%)$ most times covered their mouth and nose while coughing and 244 (58.1\%) always wore facemask in public. One hundred and 
ninety $(45.2 \%)$ reported staying indoors most times, 198 (47.1\%) never hide from people and 195 (46.4\%) said they do not go about their normal daily activities
(Table 4). Three hundred and twenty four (77.1\%) of the respondents had good practice of safety precautions against COVID19 (Fig1).

\begin{tabular}{lccc}
\multicolumn{2}{c}{ Table 3: Respondents' practice of safety precautions against COVID19 } & N $=420$ \\
\hline Variable & Yes & No & $\begin{array}{l}\text { Can't recall } \\
\text { n (\%) }\end{array}$ \\
& $\mathbf{n ~ ( \% )}$ & $\mathbf{n ~ ( \% )}$ & \\
\hline Practice of safety precautions & & & \\
Recently gone to crowded places & $196(46.7)$ & $204(48.6)$ & $20(4.8)$ \\
Recently wear mask when leaving home & $372(88.6)$ & $31(7.4)$ & $17(4.0)$ \\
Safety precautions in the event of COVID19 symptoms & & \\
Stay at home & $312(74.3)$ & $49(11.7)$ & $59(14.0)$ \\
Wear mask & $325(77.4)$ & $14(3.3)$ & $81(19.3)$ \\
Go to church & $77(18.3)$ & $229(54.5)$ & $114(27.1)$ \\
Tell no one & $73(17.4)$ & $221(52.6)$ & $126(30.0)$ \\
Inform health provider & $339(80.7)$ & $4(1.0)$ & $77(18.3)$ \\
Infect others & $14(3.3)$ & $284(67.6)$ & $122(29.0)$ \\
\hline
\end{tabular}

Table 4: Respondents' level of practice of preventive measures against COVID19

\begin{tabular}{|c|c|c|c|c|c|}
\hline \multirow[t]{3}{*}{ Variable } & \multicolumn{5}{|c|}{ Practice of preventive measures against COVID19 } \\
\hline & Never & Rarely & $\begin{array}{l}\text { Some times } \\
\text { n (\%) }\end{array}$ & $\begin{array}{l}\text { Most times } \\
\text { n (\%) }\end{array}$ & Always \\
\hline & n $(\%)$ & n (\%) & & & n (\%) \\
\hline Washing hands with soap and water & $2(0.5)$ & $24(5.7)$ & $190(45.2)$ & $159(37.9)$ & $45(10.7)$ \\
\hline Rubbing hands with alcohol based sanitizer & $11(2.6)$ & $43(10.2)$ & $72(17.1)$ & $212(50.5)$ & $82(19.5)$ \\
\hline Maintain at least 2 meters social distance & $3(0.7)$ & $47(11.2)$ & $287(68.3)$ & $55(13.1)$ & $28(6.7)$ \\
\hline Avoid touching hands, nose and mouth & $16(3.8)$ & $44(10.5)$ & $237(56.4)$ & $109(26.0)$ & $14(3.3)$ \\
\hline Cover mouth and nose when coughing & $3(0.7)$ & $44(10.5)$ & $74(17.6)$ & $190(45.2)$ & $109(26.0)$ \\
\hline Wearing facemask in public & $8(1.9)$ & $35(8.3)$ & $5(1.2)$ & $128(30.5)$ & $244(58.1)$ \\
\hline Staying indoors & $30(7.1)$ & 69 (16.4) & $103(24.5)$ & $190(45.2)$ & $28(6.7)$ \\
\hline Hide from people & $198(47.1)$ & $88(21.0)$ & $62(14.8)$ & $55(13.1)$ & $17(4.0)$ \\
\hline Go about normal daily activities & $195(46.4)$ & $88(21.0)$ & $100(23.8)$ & $28(6.7)$ & $9(2.1)$ \\
\hline
\end{tabular}

One hundred and forty five $(87.9 \%)$ of the respondents with tertiary level of education had good practice of safety precautions against COVID19 compared to 3 $(33.3 \%)$ of those with no formal education. This association was statistically significant $(\mathrm{p}<0.001)$. Nineteen $(95.0 \%)$ and $71(89.9 \%)$ of the respondents with skill levels III and IV respectively had good practice of safety precautions against COVID19 compared to $49(73.1 \%)$ of those with Skill level I occupations. This was also statistically significant ( $\mathrm{p}=$ $0.004)$. One hundred and sixty eight $(85.3 \%)$ of the respondents with good knowledge of COVID19, had good practice of safety precautions compared to 27 $(39.7 \%)$ of those with poor knowledge. This was a statistically significant association $(\mathrm{p}<0.001)$ (Table5). COVID19 took the world by storm within the last one year when it was declared a pandemic necessitating closing down of borders in many countries. Nigeria was not left out but with some control of the spread of the disease demonstrated by the daily case updates of NCDC and the need to continue businesses and schools, the lockdown has been eased off gradually with the instalment of safety precautions against the deadly disease. This study investigated the level of practice of pregnant women of these safety precautions against COVID-19. The women attending antenatal care in Benin city had a mean age of 30.4 years which tallies with the finding in a similar study done in Abakaliki (Anikwe et al, 2020) Also corroborating with literature is the finding that most of the women were married and had secondary or tertiary education (Anikwe et al, 2020).

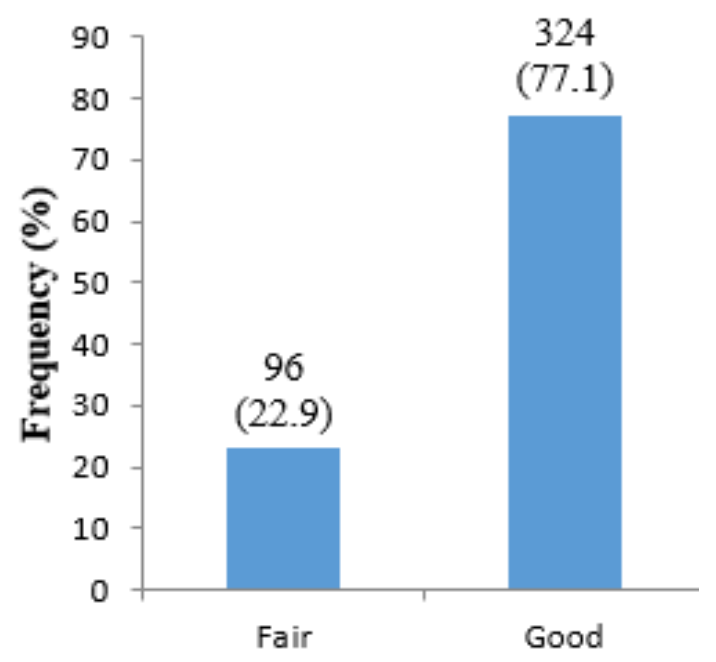

Fig 1: Respondents' level of practice of preventive measures against COVID19 
Table 5: Respondents' sociodemographic characteristics, obstetric characteristics and their practice of preventive measures against COVID19

\begin{tabular}{|c|c|c|c|c|}
\hline \multirow[t]{2}{*}{ Variable } & \multicolumn{2}{|c|}{ Practice of preventive measures } & \multirow[t]{2}{*}{ Test statistic } & \multirow[t]{2}{*}{ p value } \\
\hline & $\begin{array}{l}\text { Fair } \\
\text { n (\%) }\end{array}$ & $\begin{array}{l}\text { Good } \\
\text { n (\%) }\end{array}$ & & \\
\hline \multicolumn{5}{|l|}{ Age (years) } \\
\hline $15-19$ & $0(0.0)$ & $5(100.0)$ & $\chi^{2}=10.464$ & 0.063 \\
\hline $20-24$ & $18(30.5)$ & $41(69.5)$ & & \\
\hline $25-29$ & $28(21.4)$ & $103(78.6)$ & & \\
\hline $30-34$ & $24(17.9)$ & $110(82.1)$ & & \\
\hline $35-39$ & $14(23.0)$ & $47(77.0)$ & & \\
\hline$\geq 40$ & $12(40.0)$ & $18(60.0)$ & & \\
\hline \multicolumn{5}{|l|}{ Marital status } \\
\hline Single & $5(19.2)$ & $21(80.8)$ & $\mathrm{FE}=1.221$ & 0.961 \\
\hline Married & $91(23.5)$ & $297(76.5)$ & & \\
\hline Divorced & $0(0.0)$ & $1(100.0)$ & & \\
\hline Separated & $0(0.0)$ & $3(100.0)$ & & \\
\hline Cohabiting & $0(0.0)$ & $2(100.0)$ & & \\
\hline \multicolumn{5}{|c|}{ Level of education } \\
\hline No formal & $6(66.7)$ & $3(33.3)$ & $\chi^{2}=25.042$ & $<0.001 *$ \\
\hline Primary & $8(30.8)$ & $18(69.2)$ & & \\
\hline Secondary & $62(28.2)$ & $158(71.8)$ & & \\
\hline Tertiary & $20(12.1)$ & $145(87.9)$ & & \\
\hline \multicolumn{5}{|c|}{ Occupational classification } \\
\hline Unemployed & $7(19.4)$ & $29(80.6)$ & $\chi^{2}=15.580$ & 0.004* \\
\hline Skill level I & $18(26.9)$ & $49(73.1)$ & & \\
\hline Skill level II & $62(28.4)$ & $156(71.6)$ & & \\
\hline Skill level III & $1(5.0)$ & $19(95.0)$ & & \\
\hline \multirow{2}{*}{\multicolumn{5}{|c|}{ Parity }} \\
\hline & & & & \\
\hline 0 & $17(23.3)$ & $56(76.7)$ & $\chi^{2}=6.122$ & 0.106 \\
\hline 1 & $23(22.8)$ & $78(77.2)$ & & \\
\hline $2-4$ & $48(21.0)$ & $181(79.0)$ & & \\
\hline$\geq 5$ & $8(47.1)$ & $9(52.9)$ & & \\
\hline \multicolumn{5}{|c|}{ Estimated gestational age (weeks) } \\
\hline$\leq 12$ & $2(66.7)$ & $1(33.3)$ & $\mathrm{FE}=5.126$ & 0.358 \\
\hline $13-27$ & $22(26.8)$ & $60(73.2)$ & & \\
\hline $28-32$ & $34(20.4)$ & $133(79.6)$ & & \\
\hline $33-36$ & $21(25.0)$ & $63(75.0)$ & & \\
\hline $37-40$ & $17(21.0)$ & $64(79.0)$ & & \\
\hline$>40$ & $0(0.0)$ & $3(100.0)$ & & \\
\hline \multicolumn{5}{|c|}{ Knowledge of COVID19 } \\
\hline Poor & $41(60.3)$ & $27(39.7)$ & $\chi^{2}=64.698$ & $<0.001 *$ \\
\hline Fair & $26(16.8)$ & $129(83.2)$ & & \\
\hline Good & $29(14.7)$ & $168(85.3)$ & & \\
\hline
\end{tabular}

The fight for the education of the girl child has made tremendous progress in southern Nigeria thus such level of literacy is expected. However many of these women had skill level I or II jobs while some where housewives or students. The Nigerian woman's socioeconomic status is not judged by her occupation but that of her husband's (Nwafor et al, 2020). Many women are comfortable with lower skill level jobs such as hairdressing, tailoring and catering knowing that their husband would support the home financially. Avoidance of crowded places was done by less than half of the women in our study. This is disheartening because it becomes very difficult to maintain social distance in crowded places, thus spreading the disease in such places cannot be avoided completely. This is similar to a previous Nigerian study (Oyeyemi et al, 2020). Although the federal government made restrictions against crowding, many residents come out en masse to fend for their daily bread or to do banking transactions in order to procure food supplies. The total lockdown had inflicted significant hardship on the populace thus creating momentum for the large turn up at banks and in markets. Nonetheless steps have to be taken to enforce federal government restrictions in the form of fines and other punishments. Protocols should have been set on standing arrangements, waiting areas etc before the opening of such establishments. Majority of the customer care should have been done online and cash withdrawals at automated teller machines (ATM), this information should have been communicated to the customers before opening such establishments to avoid overcrowding. However overcrowding cannot be completely stopped unless the population put in some effort, thus more health education effort should be directed at the population on the gravity of the disease, problems of overcrowding and the individual role of the populace. The use of mask was encouraging as 
most of the women reported using masks thus limiting the spread of the disease. This is more encouraging than the findings in previous studies (CDC, 2020; Haq et al, 2020). Although there have been worldwide shortages of personal protective equipment (PPE) including facemasks and the federal government has given preference to healthcare workers in the distribution of this scarce resource. Even with multiple mixed messages on the use of face masks, the Nigerian populace has adhered to using them, especially cloth mask which has been encouraged by Centre for disease control and prevention (CDC) (CDC, 2020). This consistent mask usage may not be unconnected to the fact that designers have made cloth masks fashionable thus promoting compliance. In the event of COVID-19 symptoms, most of the women reported that they would inform a health provider, majority stated that they would wear mask and stay at home. This practice is good, because in certain European countries, patients with mild symptoms are advised to stay home to avoid overcrowding the hospitals. Going to the hospital or to a testing center should be the first step, to get tested then home isolation is advised. Following such steps would reduce overcrowding in hospitals and allow for treatment of severe cases with the scarce healthcare resources. This will eventually lead to victory against the dreaded disease according to (Anikwe et al 2020). Certain supermarkets now have restrictions against entry without use of facemasks, this has encouraged the use of facemasks significantly. Multiple hand washing points have also been sighted in market places to encourage hand washing. Crowd gathering has been labelled against the law and violators have been punished. These steps helped in the initial phase of the lockdown easing but now with large populations on the street, more has to be done to enforce compliance. It is the responsibility of every individual to comply with the laid out guideline to protect their loved ones, this should be resounded in every media platform to encourage compliance. This is in line with the work done (Zhong et al, 2020). The practice of safety precautions against COVID19 among the pregnant women in Benin City was generally good as $77.1 \%$ of them had good practice scores. This is in line with previous studies done (Zhong et al, 2020; Anikwe et al 2020). Good practice was more among those with tertiary education, higher skill level occupations, and good knowledge of COVID-19. This is corroborated in a Malaysian study (Azlan et al, 2020). The latter study showed that older age and those with better income were less likely to practice safety precautions. Thus there is apparently more influence exerted by knowledge of COVID-19 than the socioeconomic effect. There is need for extensive health education on the disease and the need for safety precaution practice.
Conclusion: The study showed a good practice of safety precautions against COVID19 and this was influenced by the women's level of education, occupation and knowledge of COVID-19. There is thus need to improve the knowledge of the women attending antenatal clinic regarding COVID-19 through health education seminars. Also up scaling the practice of safety precautions could be done through such health education seminars.

\section{REFERENCES}

Anikwe, CC; Ogah, CO; Anikwe, IH; Okorochukwu, BC; Ikeoha, CC. (2020). Coronavirus disease 2019: Knowledge, attitude, and practice of pregnant women in a tertiary hospital in Abakaliki, Southeast Nigeria. Int J Gynecol and Obstet.151: 197-202.

Azlan, AA; Hamzah, MR; Sern, TJ; Ayub, SH; Mohamad, E. (2020) Public knowledge, attitudes and practices towards COVID-19: A crosssectional study in Malaysia. PLoS One. 15(5): 115.

Beigel, JH; Tomashek, KM; Dodd, LD; Mehta, AK; Zingman, BS; Kalil, AC; Hohmann, E; Chu, HY; Luetkemeyer, A; Kline, S; Lopez de Castilla, D; Finberg, RW; Dierberg, K; Tapson, V; Hsieh, L; Patterson, TF; Paredes, R; Sweeney, DA; Short, WR; Touloumi, R; Lye, DC; Ohmagari, D; Oh, M; Ruiz-Palacios, GM; Benfield, T; Fätkenheuer, G; Kortepeter, MG; Atmar, RL; Creech, CB; Lundgren, J; Babiker, AG; Pett, S; Neaton, D; Burgess, TH; Bonnett, T; Green, M; Makowski, M; Osinusi, A; Nayak, S; Lane, HC. (2020). Remdesivir for the treatment of Covid-19 preliminary report. $N$ Eng. J. Med. 1-14.

Centre for Disease Control and Prevention (2020). Cloth face cover guidance. available at https://www.cdc.gov/coronavirus/2019ncov/prevent-getting-sick/cloth-face-coverguidance.html

Dong, L; Tian, J; He, S; Zhu, C; Wang, J; Liu, C; Yang, J. (2020). Possible vertical transmission of SARS-CoV-2 from an infected mother to her newborn. JAMA. 323 (18):1846-1848.

Haq, N; Hassali, MA; Shafie, AA; Saleem, F; Farooqui, M; Aljadhey, HA. (2012). Cross sectional assessment of knowledge, attitude and practice towards Hepatitis B among healthy population of Quetta, Pakistan. J BMC Public Health. 12 (692):1471-2458. 
International Committee on Taxonomy of Viruses. (2020). Naming the 2019 Coronavirus. Available from: https://talk.ictvonline.org.

International Standard Classification of Occupations. (2020). ISCO-08. Volume 1; Structure, Group Definitions and Correspondence Tables. International Labour Office, Geneva. 433 pp.

Kerr, SM; Parker, SE; Mitchell, AA; Tinker, SC; Werler, MM. (2017). Periconceptional maternal fever, folic acid intake, and the risk for neural tube defects. Ann Epidemiol. 27: 777-782.

Lai, CC; Shih, TP; Ko, WC; Tang, HJ; Hsueh, PR. (2020). Severe acute respiratory syndrome coronavirus 2 (SARS-CoV-2) and coronavirus disease-2019 (COVID-19): the epidemic and the challenges. Int J Antimicrob Agents 55. 1-9

Li, Q; Guan, X; Wu, P; Wang, X; Zhoug, L; Tong, Y; Ren, R; Leung, K; Lau, E; Wong, J; Xing, X; Xiang, N; Wu, Y; Li, C; Chen, Q; Li, D; Liu, T; Zhao, J; Liu, M; Tu, W; Chen, C; Jin, L; Yang, R; Wang, Q; Zhou,S; Wang, R; Liu, H; Luo, Y; Liu, Y; Shao, G; Li, H; Tao, Z; Yang, Y; Deng, Z; Liu, B; Ma, Z; Zhang, Y; Shi, G; Lam, T; Wu, J; Gao, G; Cowling, B; Yang, B; Leung, G; Feng, Z. (2020). Early transmission dynamics in Wuhan, China, of novel coronavirus-infected pneumonia. N Engl J Med. 382(13); 1199- 1207.

Lotfi, M; Hamblin, MR; Rezaei, N. (2020). COVID19: transmission, prevention, and potential therapeutic opportunities. Clin Chim Acta. 10: 529.

Lu, H; Stratton, CW; Tang, YW. (2020). Outbreak of pneumonia of unknown etiology in Wuhan, China: The mystery and the miracle. $J$ Med Virol. 92: 401-402.

Makoni, M. (2020). Africa prepares for coronavirus. Lancet. 395 (10223): 467-436.

Mullard, A. (2020). COVID-19 vaccine development pipeline gears up. Lancet. 395: 1751-1752.

Nwafor, JI; Aniukwu, JK; Anozie, BO; Ikeotuonye, AC; Okedo-Alex, IN. (2020). Pregnant women's knowledge and practice of preventive measures against COVID-19 in a low-resource African setting. Int J GynaecoL and Obstet. 15(1):121-123. pandemic: Nigerians' knowledge, perception and adherence to preventive measures. Research square. 2-19.

Shereen, MA; Khan, S; Kazmi, A; Bashir, N; Siddique, R. (2020). COVID-19 infection: origin, transmission, and characteristics of human coronaviruses. J Adv Res. 24:91-98.

Wolf, MS ; Serper, MD; Opsasnick, L; O’Conor,RM; Curtis, L; Benavente, JY; Wismer, G; Batio,S; Eifler, M; Zheng, P; Russell, A; Arvanitis, M; Ladner,D; Kwasny, M; Persell, SD;Rowe, T; DO; Linder, JA; Bailey, SC. (2020). Awareness, attitudes, and actions related to COVID-19 among adults with chronic conditions at the onset of the $\mathrm{U}$. S. outbreak. Ann Intern Med. 173(2):100-109.

World Health Organization (2020). DirectorGeneral's opening remarks at the media briefing on COVID-19. Available from: https:/www.who.int/dg/speeches/detail/whodirector-general-s-opening-remarks-at-the-mediabriefing-on-covid-19-11-march-2020.

World Health Organization. (2020). Naming the coronavirus disease (COVID-19) and the virus that causes it. 2020. Available from: https://www.who.int/emergencies/diseases/novelcoronavirus-2019/technical-guidance/naming-thecoronavirus-disease-(covid-2019)-and-the-virusthat-causes-it.

World Health Organization. (2020). Q\&A on Coronaviruses (COVID-19). Available from: https://www.who.int/emergencies/diseases/novelcoronavirus-2019/question-and-answers-hub/q-adetail/q-a-coronaviruses\#: : text=symptoms.

World Health Organization. (2020). Country \& Technical Guidance - Coronavirus disease (COVID-

19). https://www.who.int/emergencies/diseases/no vel-coronavirus-2019/technical-guidance.

Zhong, BL; Luo, W; Li, HM; Zhang, QQ; Liu, XG; Li, WT; Li, Y. (2020). Knowledge, attitudes, and practices towards COVID-19 among Chinese residents during the rapid rise period of the COVID-19 outbreak: A quick online crosssectional survey. Int $J$ Biol Sci. 16(10): 1745-1752.

Oyeyemi, O; Oladoyin, V; Okunlola, O; Mosobalaje, A; Oyeyemi, I; Adebimpe, W. (2020). COVID-19 